\title{
MECHANISMS OF IMPAIRED WATER EXCRETION IN ADRENAL AND PITUITARY INSUFFICIENCY. I. THE ROLE OF AL- TERED GLOMERULAR FILTRATION RATE AND SOLUTE EXCRETION ${ }^{1,2}$
}

\author{
By CHARLES R. KLEEMAN, MORTON H. MAXWELL, AND ROBERT E. ROCKNEY \\ (From the Department of Medicine, Veterans Administration Center, and the University of \\ California, Los Angeles, Calif.)
}

(Submitted for publication April 14, 1958; accepted July 31, 1958)

The inability to excrete an oral or parenteral load of water in a normal manner is a characteristic of the adrenalectomized or hypophysectomized animal and of the patient with adrenal or pituitary insufficiency (1-9). This defect persists in the presence of a normal salt balance, extracellular volume, and an adequate supply of salt-retaining hormone, desoxycorticosterone acetate (DCA) or aldosterone $(4,7,8,10,11)$, but it can usually be corrected by the administration of hydrocortisone-like steroids $(3,4,7,9)$.

The basic mechanisms responsible for impaired water tolerance in these diseases have not been adequately clarified, nor have the processes by which hydrocortisone causes a normal water diuresis to occur.

Gaunt, Birnie and Eversole (8) and others (7, 12) have suggested that a homeostatic "balance" exists between the antidiuretic hormone $(\mathrm{ADH})$ of the neurohypophysis and the 11, 17 hydroxylated steroids of the adrenal cortex. They suggest that in the absence of these steroids, a relative or absolute excess of $\mathrm{ADH}$ exists, preventing a normal water diuresis. To prove this hypothesis, a sustained level of secretion of $\mathrm{ADH}$ should be demonstrated after the adrenal or anterior pituitary deficient animal has been water loaded, a procedure which ordinarily inhibits ADH secretion. To date, no such sustained activity has been observed using a generally acceptable and specific assay technique $(6,13,14)$. Furthermore, the patient with adrenal or pituitary insufficiency normally inactivates and is not hypersensitive to exogenous antidiuretic hormone (Pitressin $\left.{ }^{\circledR}\right)(6)$.

\footnotetext{
${ }^{1}$ Supported in part by a research grant from the Upjohn Company.

2 Presented in part at the Annual Meeting of the American Federation for Clinical Research, May, 1957, Atlantic City, N. J.
}

Recent studies have stressed the importance of nonhormonal factors in determining the characteristics of water diuresis in normal subjects. The rate of glomerular filtration and solute excretion, and the distribution of the reabsorbed solutes between the proximal and distal tubules can profoundly alter the diuretic response to water in the absence of circulating ADH (15-21). Reduced glomerular filtration and renal blood flow are usually present in subjects with pituitary and adrenal insufficiency. In the latter, and occasionally in the former group, tubular reabsorption of sodium is impaired. Welt (22) postulated that the impaired water diuresis of these states is related primarily to alterations in the nonhormonal factors rather than to any disturbance in the secretion, metabolism, or action of $\mathrm{ADH}$. If this theory is correct, it should be possible, while these subjects are under the influence of a sustained water load, to improve considerably their response to water loading by techniques which increase glomerular filtration rate and alter the distribution of solute (sodium) reabsorption between the proximal and distal tubule.

This approach formed the basis of the present study. Aminophyllin was used to increase glomerular filtration acutely and alter the tubular reabsorption of solute. Its effect was compared in the same subject with the subsequent administration of hydrocortisone. The results indicate that the marked improvement in the execretion of water which followed the administration of hydrocortisone cannot be completely explained by improved renal hemodynamics or alteration of solute reabsorption. They support the view that Compound F-like steroids may, in the absence of $\mathrm{ADH}$, specifically inhibit the back diffusion of water in the diluting segments of the nephron (loop of Henle and distal convoluted tubule) or prevent 
TABLE I

The response to aminophyllin, Mercuhydrin and hydrocortisone in adrenal and pituitary insufficiency

\begin{tabular}{|c|c|c|c|c|c|c|c|c|c|c|}
\hline $\begin{array}{l}\text { Subject } \\
\text { Date }\end{array}$ & Period & $\begin{array}{c}\text { Urine } \\
\text { volume }\end{array}$ & $\begin{array}{c}\text { Urine } \\
\text { concen- } \\
\text { tration }\end{array}$ & Uom V* & $\mathrm{C}_{\mathrm{Bg}_{8} \mathrm{O}}$ & $\begin{array}{c}\text { Glomerular } \\
\text { filtration } \\
\text { rate } \\
\text { (GFR) }\end{array}$ & $\frac{\mathrm{CH}_{\mathrm{B}} \mathrm{O}}{\mathrm{GFR}} \times 100$ & $\mathrm{UNaV}_{\mathrm{Na}}$ & UsV & $\begin{array}{c}\text { Serum } \\
\text { osmolality }\end{array}$ \\
\hline & & ml./min. & $\underset{\mathbf{K}_{\mathbf{g}}}{\operatorname{mosm} . /}$ & $\begin{array}{c}\text { mOsm.I } \\
\text { min. }\end{array}$ & ml./min. & ml./min. & & $\mu E q . / m i n$ & $\mu E q_{.} / m i n$. & $\begin{array}{c}\text { mOsm.I } \\
K_{\mathbf{B}} .\end{array}$ \\
\hline \multicolumn{11}{|c|}{ Anterior pituitary insufficiency } \\
\hline $\begin{array}{c}1 \\
4 / 25 / 57\end{array}$ & $\begin{array}{c}\mathrm{C} \ddagger \\
\mathrm{Am} \& \\
\mathrm{Cp} F \S\end{array}$ & $\begin{array}{l}1.2 \\
7.1 \\
9.8\end{array}$ & $\begin{array}{l}432 \\
250 \\
109\end{array}$ & $\begin{array}{r}518 \\
1,832 \\
1,068\end{array}$ & $\begin{array}{l}-0.65 \\
+0.6 \\
+5.5\end{array}$ & $\begin{array}{r}74 \\
114 \\
102\end{array}$ & $\begin{array}{l}-0.95 \\
+0.53 \\
+5.4\end{array}$ & $\begin{array}{l}141 \\
696 \\
282\end{array}$ & $\begin{array}{r}42 \\
181 \\
51\end{array}$ & $\begin{array}{l}280 \\
283 \\
250\end{array}$ \\
\hline$\stackrel{2}{11 / 15 / 56}$ & $\underset{\mathrm{Am}}{\mathrm{C}}$ & $\begin{array}{l}2.0 \\
7.2\end{array}$ & $\begin{array}{l}398 \\
232\end{array}$ & $\begin{array}{r}836 \\
1,670\end{array}$ & $\begin{array}{l}-1.2 \\
+0.8\end{array}$ & $\begin{array}{r}92 \\
105\end{array}$ & $\begin{array}{l}-1.2 \\
+0.8\end{array}$ & $\begin{array}{l}391 \\
868\end{array}$ & $\begin{array}{l}43 \\
52\end{array}$ & $\begin{array}{l}262 \\
260\end{array}$ \\
\hline $\begin{array}{c}3 \\
8 / 16 / 56\end{array}$ & $\underset{\mathrm{Am}}{\mathrm{C}}$ & $\begin{array}{r}3.2 \\
21.0\end{array}$ & $\begin{array}{l}319 \\
217\end{array}$ & $\begin{array}{l}1,021 \\
4,557\end{array}$ & $\begin{array}{r}-0.9 \\
+3.2\end{array}$ & $\begin{array}{r}71 \\
131\end{array}$ & $\begin{array}{l}-1.5 \\
+2.7\end{array}$ & $\begin{array}{r}322 \\
2,010\end{array}$ & $\begin{array}{r}91 \\
170\end{array}$ & $\begin{array}{l}248 \\
256\end{array}$ \\
\hline $\begin{array}{c}3 \\
10 / 29 / 56\end{array}$ & $\underset{\mathrm{Cp} \mathrm{F}}{\mathrm{Am}}$ & $\begin{array}{r}3.5 \\
8.5 \\
11.7\end{array}$ & $\begin{array}{l}424 \\
300 \\
177\end{array}$ & $\begin{array}{l}1,484 \\
2,550 \\
2,070\end{array}$ & $\begin{array}{l}-2.0 \\
-0.9 \\
+\quad 3.9\end{array}$ & $\begin{array}{r}88 \\
137 \\
110\end{array}$ & $\begin{array}{l}-2.4 \\
\overline{-} 0.2 \\
+4.3\end{array}$ & $\begin{array}{l}663 \\
810 \\
781\end{array}$ & $\begin{array}{r}70 \\
95 \\
137\end{array}$ & $\begin{array}{l}268 \\
270 \\
264\end{array}$ \\
\hline $\begin{array}{c}4 \\
2 / 18 / 57\end{array}$ & $\underset{\mathrm{Cp} \mathrm{F}}{\mathrm{C}}$ & $\begin{array}{r}7.5 \\
12.0 \\
8.4\end{array}$ & $\begin{array}{l}107 \\
145 \\
110\end{array}$ & $\begin{array}{r}803 \\
1,740 \\
924\end{array}$ & $\begin{array}{l}+4.6 \\
+5.8 \\
+5.0\end{array}$ & $\begin{array}{l}112 \\
164 \\
114\end{array}$ & $\begin{array}{l}+4.1 \\
+3.5 \\
+4.4\end{array}$ & $\begin{array}{l}140 \\
486 \\
189\end{array}$ & $\begin{array}{r}68 \\
166 \\
68\end{array}$ & $\begin{array}{l}280 \\
280 \\
275\end{array}$ \\
\hline 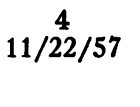 & $\underset{\mathrm{Cp} \mathrm{F}}{\mathrm{Am}}$ & $\begin{array}{l}2.3 \\
8.9 \\
7.6\end{array}$ & $\begin{array}{l}363 \\
260 \\
116\end{array}$ & $\begin{array}{r}860 \\
2,340 \\
879\end{array}$ & $\begin{array}{l}-0.9 \\
+0.3 \\
+4.3\end{array}$ & $\begin{array}{r}82 \\
106 \\
92\end{array}$ & $\begin{array}{r}-1.0 \\
+0.3 \\
+4.7\end{array}$ & $\begin{array}{l}316 \\
968 \\
199\end{array}$ & $\begin{array}{l}39 \\
73 \\
64\end{array}$ & $\begin{array}{l}270 \\
271 \\
270\end{array}$ \\
\hline $\begin{array}{c}4 \\
12 / 6 / 57\end{array}$ & $\underset{\mathrm{CpF}}{\mathrm{Hg}}$ & $\begin{array}{r}2.7 \\
11.8 \\
3.8\end{array}$ & $\begin{array}{l}273 \\
273 \\
176\end{array}$ & $\begin{array}{r}764 \\
3,208 \\
674\end{array}$ & $\begin{array}{l}-0.1 \\
-0.1 \\
+1.3\end{array}$ & $\begin{array}{l}81 \\
82 \\
82\end{array}$ & $\begin{array}{l}-0.1 \\
=0.1 \\
+1.6\end{array}$ & $\begin{array}{r}169 \\
1,499 \\
170\end{array}$ & $\begin{array}{l}43 \\
22 \\
76\end{array}$ & $\begin{array}{l}272 \\
270 \\
265\end{array}$ \\
\hline $\begin{array}{c}5 \\
2 / 4 / 57\end{array}$ & $\underset{\mathrm{Cp} \mathrm{F}}{\mathrm{Am}}$ & $\begin{array}{l}0.4 \\
4.3 \\
8.0\end{array}$ & $\begin{array}{r}590 \\
337 \\
66\end{array}$ & $\begin{array}{r}236 \\
1,463 \\
528\end{array}$ & $\begin{array}{l}-0.4 \\
-0.8 \\
+6.1\end{array}$ & $\begin{array}{r}93 \\
140 \\
97\end{array}$ & $\begin{array}{l}-0.4 \\
-0.5 \\
+\quad 6.2\end{array}$ & $\begin{array}{r}48 \\
425 \\
130\end{array}$ & $\begin{array}{l}18 \\
71 \\
68\end{array}$ & $\begin{array}{l}291 \\
287 \\
276\end{array}$ \\
\hline $\begin{array}{c}6 \\
2 / 6 / 57\end{array}$ & $\underset{\mathrm{Cp} \mathrm{F}}{\mathrm{Am}}$ & $\begin{array}{l}0.7 \\
4.4 \\
2.2\end{array}$ & $\begin{array}{l}563 \\
330 \\
244\end{array}$ & $\begin{array}{r}394 \\
1,452 \\
539\end{array}$ & $\begin{array}{l}-0.8 \\
=1.0 \\
+0.1\end{array}$ & $\begin{array}{l}50 \\
76 \\
68\end{array}$ & $\begin{array}{l}-14.0 \\
-1.3 \\
+0.1\end{array}$ & $\begin{array}{r}55 \\
583 \\
212\end{array}$ & $\begin{array}{l}30 \\
43 \\
61\end{array}$ & $\begin{array}{l}267 \\
268 \\
261\end{array}$ \\
\hline $\begin{array}{c}7 \\
12 / 27 / 57\end{array}$ & $\underset{\mathrm{Cp} \mathrm{F}}{\mathrm{C}}$ & $\begin{array}{r}0.4 \\
10.6 \\
2.7\end{array}$ & $\begin{array}{l}643 \\
253 \\
240\end{array}$ & $\begin{array}{r}270 \\
2,687 \\
648\end{array}$ & $\begin{array}{r}-0.6 \\
0.0 \\
+0.1\end{array}$ & $\begin{array}{l}53 \\
57 \\
42\end{array}$ & $\begin{array}{r}-1.1 \\
0.0 \\
+0.2\end{array}$ & $\begin{array}{r}49 \\
1,395 \\
283\end{array}$ & $\begin{array}{l}25 \\
14 \\
47\end{array}$ & $\begin{array}{l}260 \\
253 \\
245\end{array}$ \\
\hline$\stackrel{8}{8}$ & $\underset{\mathrm{Cp} \mathrm{F}}{\mathrm{C}}$ & $\begin{array}{l}1.0 \\
3.4\end{array}$ & $\begin{array}{l}355 \\
355 \\
213\end{array}$ & $\begin{array}{r}362 \\
1,207\end{array}$ & $\begin{array}{l}=0.3 \\
-1.2\end{array}$ & $\begin{array}{l}41 \\
94\end{array}$ & $\begin{array}{l}-0.7 \\
-\quad 1.1\end{array}$ & $\begin{array}{r}85 \\
454\end{array}$ & $\begin{array}{l}28 \\
60\end{array}$ & $\begin{array}{l}270 \\
265 \\
268\end{array}$ \\
\hline$\stackrel{8}{1 / 3 / 57}$ & $\underset{\mathrm{Cp} \mathrm{F}}{\mathrm{Cg}}$ & $\begin{array}{r}1.8 \\
10.0 \\
2.7\end{array}$ & $\begin{array}{l}642 \\
292 \\
188\end{array}$ & $\begin{array}{r}1,156 \\
2,935 \\
508\end{array}$ & $\begin{array}{l}-2.4 \\
-0.8 \\
+0.8\end{array}$ & $\begin{array}{l}73 \\
78 \\
57\end{array}$ & $\begin{array}{l}-3.4 \\
-1.0 \\
+1.4\end{array}$ & $\begin{array}{r}211 \\
1,296 \\
97\end{array}$ & $\begin{array}{l}83 \\
48 \\
48\end{array}$ & $\begin{array}{l}274 \\
271 \\
270\end{array}$ \\
\hline \multicolumn{11}{|c|}{ Adrenal insufficiency } \\
\hline$\stackrel{9}{11 / 8 / 57}$ & $\underset{\mathrm{CpF}}{\stackrel{\mathrm{C}}{\mathrm{Hg}}}$ & $\begin{array}{r}4.5 \\
10.0 \\
9.2\end{array}$ & $\begin{array}{l}159 \\
215 \\
138\end{array}$ & $\begin{array}{r}722 \\
2,150 \\
1,263\end{array}$ & $\begin{array}{l}+1.8 \\
+1.9 \\
+4.4\end{array}$ & $\begin{array}{l}90 \\
88 \\
88\end{array}$ & $\begin{array}{l}+2.0 \\
+\quad 2.4 \\
+5.0\end{array}$ & $\begin{array}{l}174 \\
903 \\
417\end{array}$ & $\begin{array}{l}49 \\
44 \\
81\end{array}$ & $\begin{array}{l}267 \\
267 \\
264\end{array}$ \\
\hline $\begin{array}{c}10 \\
10 / 16 / 57\end{array}$ & $\underset{\mathrm{Cp} \mathrm{F}}{\mathrm{Am}}$ & $\begin{array}{r}1.6 \\
5.2 \\
18.6\end{array}$ & $\begin{array}{r}581 \\
480 \\
80\end{array}$ & $\begin{array}{r}930 \\
2,496 \\
1,488\end{array}$ & $\begin{array}{l}-1.8 \\
=3.9 \\
+13.3\end{array}$ & $\begin{array}{l}155 \\
225 \\
169\end{array}$ & $\begin{array}{l}-1.1 \\
=1.7 \\
+7.9\end{array}$ & $\begin{array}{l}206 \\
844 \\
268\end{array}$ & $\begin{array}{r}60 \\
78 \\
104\end{array}$ & $\begin{array}{l}277 \\
274 \\
281\end{array}$ \\
\hline $\begin{array}{l}11 \\
3 / 27 / 57\end{array}$ & $\underset{\mathrm{Cp} \mathrm{F}}{\mathrm{Cm}}$ & $\begin{array}{r}5.7 \\
15.3 \\
20.0\end{array}$ & $\begin{array}{r}132 \\
160 \\
80\end{array}$ & $\begin{array}{r}752 \\
2,448 \\
1,600\end{array}$ & $\begin{array}{r}+3.1 \\
+\quad 6.8 \\
+14.4\end{array}$ & $\begin{array}{r}84 \\
105 \\
110\end{array}$ & $\begin{array}{l}+3.45 \\
+6.5 \\
+12.2\end{array}$ & $\begin{array}{r}207 \\
1,180 \\
510\end{array}$ & $\begin{array}{l}12 \\
26 \\
77\end{array}$ & $\begin{array}{l}285 \\
289 \\
285\end{array}$ \\
\hline $\begin{array}{c}12 \\
10 / 4 / 56\end{array}$ & $\underset{\mathrm{Cp} F}{\mathrm{Am}}$ & $\begin{array}{l}0.8 \\
5.9 \\
5.8\end{array}$ & $\begin{array}{r}397 \\
159 \\
78\end{array}$ & $\begin{array}{l}317 \\
925 \\
462\end{array}$ & $\begin{array}{r}-0.5 \\
+2.3 \\
+4.0\end{array}$ & $\begin{array}{l}76 \\
86 \\
76\end{array}$ & $\begin{array}{r}-0.5 \\
+2.7 \\
+4.7\end{array}$ & $\begin{array}{l}16 \\
67 \\
41\end{array}$ & $\begin{array}{r}14 \\
101 \\
72\end{array}$ & $\begin{array}{l}253 \\
259 \\
255\end{array}$ \\
\hline
\end{tabular}

* Rate of solute excretion.

f Free water clearance.

Represents the mean of the two control periods prior to the administration of the drug.

Represents the period of maximal change following drug administration. 
the reabsorption or back diffusion of water in the concentrating segment (? collecting tubule) $(3,23)$.

\section{METHODS AND PROCEDURE}

Sixteen experiments were performed on 12 male subjects: 8 patients with anterior pituitary insufficiency and 4 with primary adrenal insufficiency. On the morning of the test, the subjects ate a light breakfast from 7:00 to 7:30 a.m., and the experiment began at approximately 8:30 a.m. The recumbent position was maintained throughout the experiment. An initial urine specimen was obtained for osmolality, after which an oral water load of $1,000 \mathrm{ml}$. was given; this positive water balance was maintained for the duration of the experiment by the infusion of 2.5 per cent glucose in water at a rate equal to urine flow. In a few instances, when flows exceeded 15 to $20 \mathrm{ml}$. per minute, supplemental water was given by mouth. Collection periods were 20 to 30 minutes in duration, and urine samples were collected by spontaneous voiding or by indwelling catheters. When urine volume was below $2 \mathrm{ml}$. per minute, air "washouts" were also utilized. Samples of venous blood were obtained at the midpoint of each period through an indwelling needle. Control collections were begun about 45 minutes after a priming dose of inulin and a constant sustaining infusion had been started. After at least three control periods of maximally sustained urinary flow had been obtained, 0.5 to $0.65 \mathrm{Gm}$. of aminophyllin (or $2 \mathrm{ml}$. of Mercuhydrin(8) was injected over a 10 minute period into the infusion tubing. After a maximal effect of aminophyllin or the mercurial had been observed and urinary flows had returned toward those of the control periods (90 to 150 minutes), $200 \mathrm{mg}$. of hydrocortisone (hemisuccinate) was administered into the infusion tubing over a period of 30 minutes. Urinary collections were continued for an additional three to five hours. The

TABLE II

Urinary osmolality before and after water ingestion

\begin{tabular}{ccc}
\hline $\begin{array}{c}\text { Subject } \\
\text { no. }\end{array}$ & Before & After \\
\hline & mOsm./Kg. & mOsm./Kg. \\
1 & 570 & 432 \\
2 & 453 & 398 \\
3 & 727 & 424 \\
3 & 515 & 319 \\
4 & 400 & 273 \\
4 & 420 & 363 \\
4 & 255 & 107 \\
5 & 700 & 590 \\
6 & 690 & 563 \\
7 & 780 & 643 \\
8 & 800 & 642 \\
8 & 520 & 355 \\
9 & 279 & 159 \\
10 & 680 & 581 \\
11 & 678 & 132 \\
12 & 510 & 397 \\
\hline
\end{tabular}

experiments ranged from five and one-half to eight hours in duration. ${ }^{3}$

Analysis of serum and urine for sodium, potassium, chloride, inulin, creatinine and freezing point depression (osmolality: mOsm. per $\mathrm{Kg}$. of $\mathrm{H}_{2} \mathrm{O}$ ) were made utilizing methods previously reported $(14,15)$. The characteristics of the water diuresis were evaluated in each case by maximal urinary flow, minimal urinary osmolality and the magnitude of the free water clearance, $\mathrm{C}_{\mathrm{H}_{2} 0 .}{ }^{4}$

Since the experiments were too rigorous to permit control water loading studies without drug administration on each subject, urine volumes were measured in three patients (two pituitary and one adrenal insufficiency) maintained in sustained positive water balance for five hours; in these three control subjects, maximal urinary flows were attained in the first two and one-half hours.

Following the infusion of aminophyllin, abrupt increases in urinary flow occurred. This introduced an error, created by the urinary dead space, which overestimated the rise in solute excretion and glomerular filtration rate and underestimated the fall in urinary osmolality. In the present experiments, however, it is doubtful that these errors would qualitatively alter the results or their interpretations.

\section{RESULTS}

The significant data from each study are presented in Table I. Individual studies are described in greater detail when these deviate significantly from the general pattern.

\section{Patients with adrenal or pituitary insufficiency}

A. Response to water loading. All initial urine specimens were significantly hypertonic. Following water ingestion, a distinct fall in urinary osmolality occurred in every case (Table II). The maximal urinary flow was attained after a time interval comparable to that of normal subjects (14), suggesting that in these patients inhibition of $\mathrm{ADH}$ secretion did occur (Table III). An

${ }^{3}$ Administration of steroids always followed that of aminophyllin or mercurials. This was because the duration of action of the latter drugs is relatively brief, whereas the effects of a single dose of hydrocortisone may persist for 12 to 24 hours (24).

$4 \mathrm{C}_{\mathrm{H}_{2} \mathrm{O}}$ is equivalent to the volume of urine per minute virtually freed of solute during the diluting process. It represents the difference between total urinary flow, V, and the volume of fluid necessary to excrete all the urinary solutes in an isosmotic solution or the osmolar clearance, Cosm. :

$$
\mathrm{V}-\mathrm{C}_{\text {osu. }}=\mathrm{C}_{\mathrm{H} 20} \text {. }
$$

A thorough discussion of the derivation of these terms has been presented in previous publications $(25,26)$. 
TABLE III

The effect of the water load on the glomerular filtration rate (GFR) and the time necessary to attain maximal flow *

\begin{tabular}{ccc}
\hline \hline Time & $\begin{array}{c}\text { GFR } \\
\text { (initial periods) } \dagger\end{array}$ & $\begin{array}{c}\text { GFR } \\
\text { (maximal flow) }\end{array}$ \\
\hline $\min$. & ml./min. & ml./min. \\
98.3 & 85 & 82 \\
(range, 60-126) & (range, 52-133) & (range, 50-136) \\
\hline
\end{tabular}

* The values represent the means of all the patients with impaired water diuresis.

t The mean of the first two clearance periods.

increase in glomerular filtration rate at the peak of diuresis, as described by Burston and Garrod (27), was not observed (Table III). The magnitude of the peak diuresis was distinctly subnormal (maximal mean urinary flow, $2.4 \mathrm{ml}$. per minute; range, 0.4 to $7.5 \mathrm{ml}$.; mean urinary osmolality, 409 mOsm. per $\mathrm{Kg}$. ; range, 107 to 643 ), as was the free water clearance per $100 \mathrm{ml}$. of glomerular filtrate (28) (Table I and Figure 3). Although the rate of urinary flow could be correlated to some extent with solute excretion $(r=0.38)$ or with glomerular filtration rate $(r=0.22)$ (Figures 1 and 2), the correlation was much poorer than that observed in normal subjects $(15,16)$. Although three of the patients with subnormal diuresis (Nos. 4, 9, 11) were able to form a moderately hypotonic urine, their rate of glomerular filtration and solute excretion did not differ appreciably from those patients whose control urines were hypotonic (Table I). ${ }^{5}$

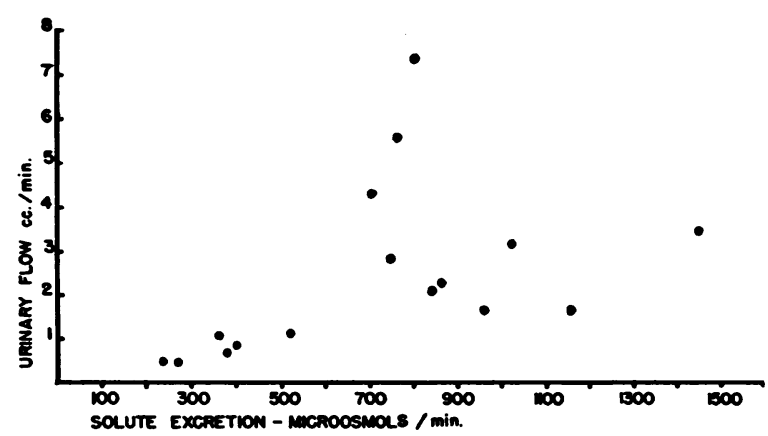

Fig. 1. The Relationship of Maximal Urinary Flow to Total Solute Excretion in Patients with Adrenal and Pituitary Insufficiency

Each point represents one patient.

5 The distinct deterioration in water diuresis and glomerular filtration observed in Patient No. 4 between his first $(2 / 57)$ and second $(11 / 57)$ studies was associated with a failure to take hydrocortisone therapy for the entire interval beginning two weeks before the first study.
B. Response to aminophyllin or Mercuhydrin Following the administration of aminophyllin, urinary flow increased abruptly in every patient (Table I and Figure 3), attaining a maximal rate within 20 to 40 minutes. The mean increase in flow was $8.2 \mathrm{ml}$. per minute, with a range of 3.6 to 18. The smallest absolute but the greatest percentile increments occurred in those subjects with the lowest control urinary flows. The diuresis seemed adequately explained by the associated acute increases in both glomerular filtration rate and solute excretion. Filtration rate increased an average of $42 \mathrm{ml}$. per minute and generally returned to the control level within one hour. The mean increase in solute excretion was 1,487 $\mu$ Osm. per minute. Although peak excretion of urinary solutes coincided with the maximal rise in glomerular filtration rate and urinary flow, the subsequent decline in solute excretion was more gradual and was still somewhat above control levels when hydrocortisone was administered (Figure 3).

The qualitative change in urinary osmolality and free water clearance $\left(\mathrm{C}_{\mathrm{H}_{2} \mathrm{O}}\right)$ following the administration of aminophyllin was dependent solely on the urinary osmolality during the control periods. Those patients with distinctly hypotonic control urines (Nos. 4 and 11, Table I, 45 to 132 mOsm. per Kg.) had an increase in urinary osmolality and $\mathrm{C}_{\mathrm{H}_{2} \mathrm{O}}$ regardless of the magnitude of the change in solute excretion or glomerular filtration rate (Table I). This is the characteristic response to an increase in solute excretion and/or filtration rate during a maximal sustained water diuresis in normal subjects $(16,21,22)$. Those whose control urines were slightly $h y$ pertonic, but did not exceed $500 \mathrm{mOsm}$. per $\mathrm{Kg}$. (Table I), had not only increased $\mathrm{C}_{\mathrm{H}_{2} \mathrm{O}}$ and urinary flow, but distinctly decreased urinary osmolality. These changes indicated a more normal or improved water diuresis following the injection of aminophyllin. Urinary osmolality decreased from a mean value of 409 to 219 mOsm. per $\mathrm{Kg}$. while $\mathrm{C}_{\mathrm{H}_{2} \mathrm{O}}$ increased from a mean negative value of -1.3 to +1.3 , a mean algebraic increase of $2.6 \mathrm{ml}$. per minute.

Because of the small size of this group, statistical correlations between changes in osmolality and $\mathrm{C}_{\mathrm{H}_{2} \mathrm{O}}$ and in glomerular filtration and solute excretion were not attempted. It is of interest, 
however, that of the two subjects with the most marked rise in $\mathrm{C}_{\mathrm{H}_{2} \mathrm{O}}$ and fall in urinary osmolality (Nos. 3 and 12, Table I), one (No. 3) had the largest increase in glomerular filtration and solute excretion while the other (No. 12) had the smallest. In addition, one other subject (No. 8) had a twofold increase in filtration rate, a fourfold increase in solute excretion, and a threefold increase in urinary flow without an appreciable change in his control osmolality of 355 .

In those patients whose control urinary osmolalities exceeded $500 \mathrm{mOsm}$. per $\mathrm{Kg}$. (Nos. 5, 6, 10, Table I), the administration of aminophyllin caused a decrease in osmolality and in $\mathrm{C}_{\mathbf{H}_{2} \mathrm{O}}$. This is the characteristic effect of an increase in solute excretion on a urine of low volume but high osmolality (usually indicating a moderately high if not maximal level of $\mathrm{ADH}$ activity) $(29,30)$.

To determine whether the increase in $\mathrm{C}_{\mathbf{B}_{2} \mathrm{O}}$ and decrease in urinary osmolality after aminophyllin was due to an increased rate of solute excretion and increased glomerular filtration, it was necessary to increase the excretion of solute without elevating the rate of filtration. For this purpose, Mercuhydrin was administered to four patients (Nos. 4, 7, 8 and 9) at the height of their water diuresis. In two of the subjects (4 and 8 ) it was possible to compare the effect of aminophyllin to that of the mercurial in paired experiments.

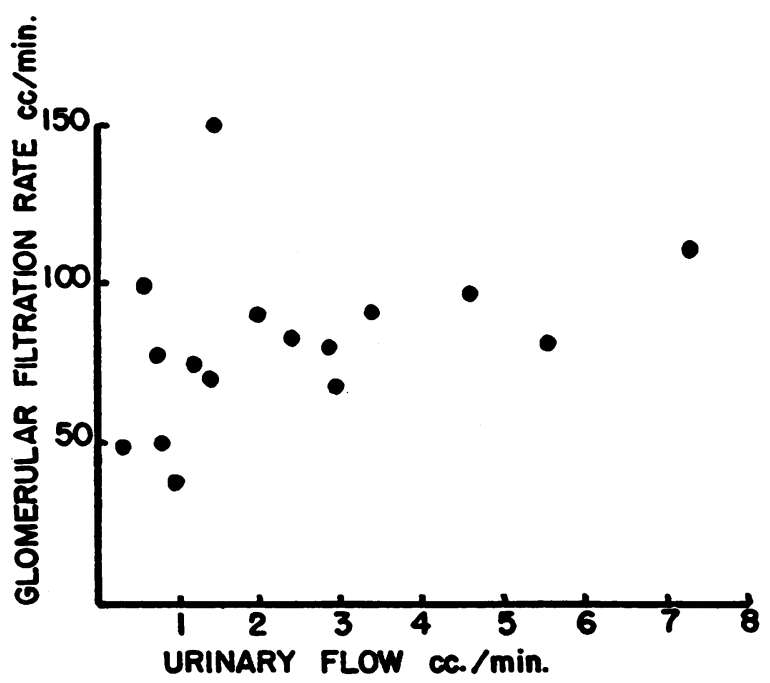

Fig. 2. The Relationship of Maximal Urinary Flow to Glomerular Filtration Rate in Patients with Adrenal and Pituitary Insufficiency

Each point represents one patient.

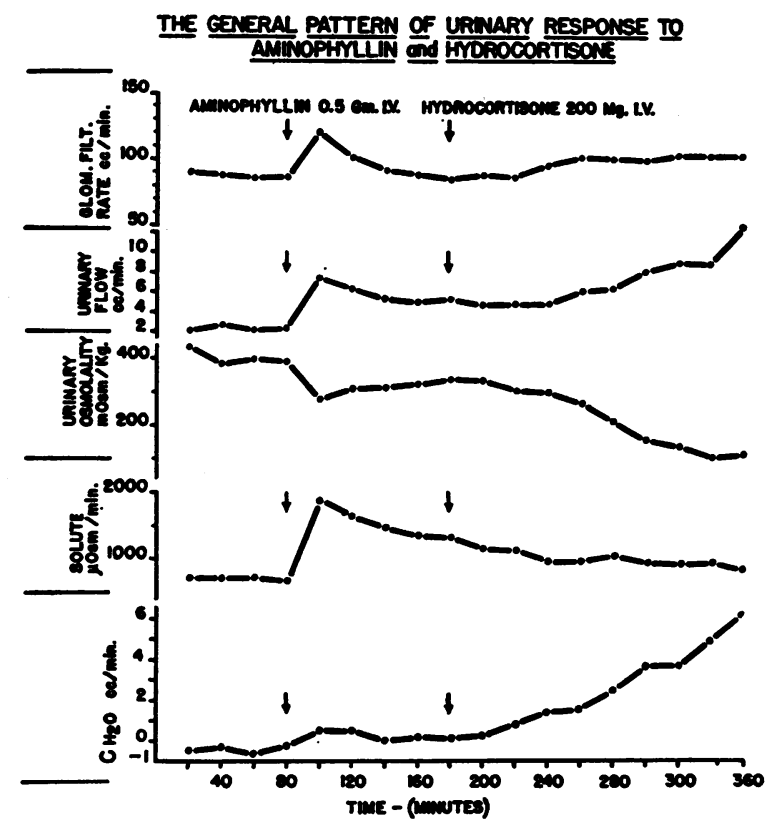

Fig. 3. The Pattern of Response to AminophylLin ANd Hydrocortisone in Those Patients with IMPAIRED Water DiUREsis

Each line (point) represents the mean value for the entire group at that period of the experiment.

In contrast to the immediate response of urinary flow and solute excretion to aminophyllin, Mercuhydrin ${ }^{\circledR}$ caused a gradual increase in solute excretion and urinary flow which reached its peak in two and one-half to three hours. It had no effect on glomerular filtration rate. Patient No. 9 was forming a hypotonic urine when the mercurial was given and, as expected, had a rise in osmolality and $\mathrm{C}_{\mathrm{H}_{2} \mathrm{O}}$ (Table I). The paired studies in Patients No. 4 and 8 (Table I) do not suggest a consistent difference between the response to the mercurial and to aminophyllin which could be attributed to the latter's effect on glomerular filtration rate. The response to Mercuhydrin in Patients No. 7 and 8 is presented in detail in Table IV. Mercuhydrin ${ }^{8}$ caused a marked increase in solute excretion and urinary flow while urinary osmolality fell from 643 and 642 to 253 and $292 \mathrm{mOsm}$. per $\mathrm{Kg}$., respectively, and $\mathrm{C}_{\mathrm{H}_{2} \mathrm{O}}$ became less negative in both instances. As noted earlier, when aminophyllin was given to patients whose control urinary osmolality exceeded $500 \mathrm{mOsm}$. per $\mathrm{Kg}$., it always caused a decrease in $\mathrm{C}_{\mathrm{H}_{2} \mathrm{O}}$ or an increase 
TABLE IV

The effect of Mercuhydrin (3) on the impaired water diuresis of two patients with anterior pituitary insufficiency

\begin{tabular}{|c|c|c|c|c|c|c|c|}
\hline Period & Time & $\begin{array}{l}\text { Urine } \\
\text { flow }\end{array}$ & $\begin{array}{c}\text { Urine } \\
\text { osmolality }\end{array}$ & $\begin{array}{c}\text { Solute } \\
\text { excretion }\end{array}$ & $\begin{array}{c}\text { Free } \\
\text { water } \\
\text { clearance } \\
\left(\mathrm{C}_{\mathrm{H}} \mathrm{O}\right)\end{array}$ & $\begin{array}{c}\text { Glomerular } \\
\text { filtration } \\
\text { rate } \\
\text { (GFR) }\end{array}$ & $\begin{array}{c}\text { Serum } \\
\text { osmolality }\end{array}$ \\
\hline \multicolumn{8}{|c|}{ Subject no. 7} \\
\hline $\begin{array}{l}1 \\
2 \\
3^{*} \\
4 \\
5 \\
6 \\
7 \\
8 \\
9\end{array}$ & $\begin{array}{l}30.5 \\
30.5 \\
30.0 \\
30.0 \\
33.0 \\
27.5 \\
29.5 \\
30.5 \\
19.5\end{array}$ & $\begin{array}{r}0.4 \\
0.4 \\
0.4 \\
0.7 \\
0.3 \\
1.1 \\
6.2 \\
10.6 \\
8.8\end{array}$ & $\begin{array}{l}626 \\
626 \\
643 \\
568 \\
660 \\
519 \\
291 \\
253 \\
261\end{array}$ & $\begin{array}{r}269 \\
257 \\
270 \\
386 \\
211 \\
586 \\
1,795 \\
2,687 \\
2,302\end{array}$ & $\begin{array}{r}-0.6 \\
-0.6 \\
-0.6 \\
-0.8 \\
-1.3 \\
-1.2 \\
-0.9 \\
0.0 \\
-0.3\end{array}$ & $\begin{array}{l}\mathbf{5 4} \\
\mathbf{5 2} \\
\mathbf{5 3} \\
\mathbf{5 0} \\
\mathbf{4 1} \\
\mathbf{4 9} \\
\mathbf{5 5} \\
\mathbf{5 7} \\
\mathbf{5 6}\end{array}$ & $\begin{array}{l}257 \\
260 \\
253 \\
253 \\
257\end{array}$ \\
\hline \multicolumn{8}{|c|}{ Subject no. 8} \\
\hline $\begin{array}{l}1 \\
2 * \\
3 \\
4 \\
5 \\
6 \\
7\end{array}$ & $\begin{array}{l}30.0 \\
60.0 \\
29.0 \\
38.0 \\
44.0 \\
29.0 \\
19.0\end{array}$ & $\begin{array}{r}1.8 \\
1.8 \\
0.6 \\
1.1 \\
4.2 \\
6.8 \\
10.0\end{array}$ & $\begin{array}{l}642 \\
642 \\
620 \\
610 \\
365 \\
323 \\
292\end{array}$ & $\begin{array}{r}1,156 \\
1,156 \\
341 \\
677 \\
1,518 \\
2,183 \\
2,935\end{array}$ & $\begin{array}{l}-2.5 \\
-2.5 \\
-0.8 \\
-1.4 \\
-1.4 \\
-1.3 \\
-0.8\end{array}$ & $\begin{array}{l}53 \\
64 \\
54 \\
73 \\
74 \\
72 \\
72\end{array}$ & $\begin{array}{l}274 \\
271 \\
271 \\
271\end{array}$ \\
\hline
\end{tabular}

* At the end of this period, $2 \mathrm{ml}$. of Mercuhydrin (B) was given intravenously.

in the negative $\mathrm{C}_{\mathrm{H}_{2} \mathrm{O}}$ in spite of a significant increase in filtration rate (Nos. 5 and 10, Table I).

The data presented indicate that when the urine is moderately hypertonic an abrupt increase in solute excretion without a change in the rate of

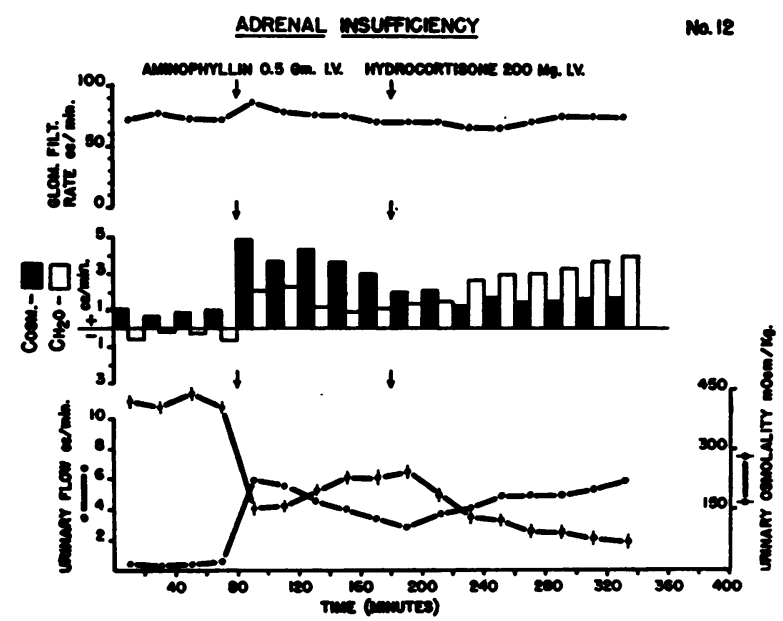

Fig. 4. The Effect of Aminophyllin and Hydrocortisone on the Water Diuresis of a Patient with Adrenal Insufficiency

Note the rather marked drop in urinary osmolality after aminophyllin associated with the rise in solute excretion and the minimal increase in glomerular filtration rate. Hydrocortisone caused a further decrease in urinary osmolality. glomerular filtration can cause a marked decrease in urinary osmolality with an increase in $\mathrm{C}_{\mathrm{H}_{2} \mathrm{O}}$ $(18,21)$.

C. Response to hydrocortisone. A noticeable increase in urinary flow, fall in urinary osmolality, and, in some instances, an increase in glomerular filtration rate, occurred within one and one-half hours after administering the steroid. The peak response was observed in three to four hours (Figure 3). Had it been possible to continue the experiments longer, a more marked change might have been observed (24). The usual response to hydrocortisone is illustrated in Figures 3 through 6. The difference from both the control and postaminophyllin or mercurial periods was striking. After administering Compound $F$ to the patients with impaired water diuresis, the urinary osmolality was consistently lower and the $\mathrm{C}_{\mathbf{H}_{2} \mathrm{O}}$ was consistently higher than the values obtained in the same patient after aminophyllin or Mercuhydrin ${ }^{8}$, despite the fact that glomerular filtration rate and solute excretion were lower. In short, hydrocortisone caused profound improvement in all the characteristics of the water diuresis.

The peak increase in $\mathrm{C}_{\mathrm{H}_{2} \mathrm{O}}$ and the lowest osmolality attained after aminophyllin or Mercuhydrin ${ }^{\circledR}$ averaged $+1.0 \mathrm{ml}$. per minute and $266 \mathrm{mOsm}$. per $\mathrm{Kg}$., respectively. Hydrocortisone caused an 


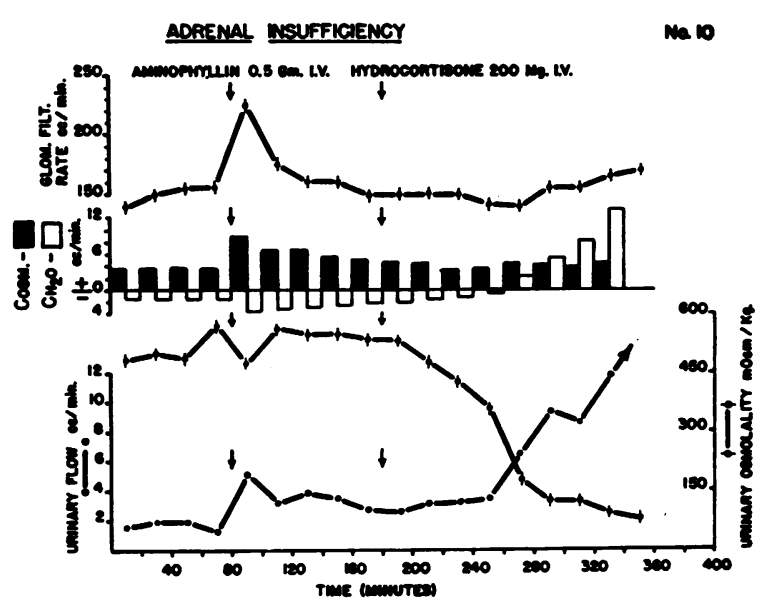

Fig. 5. The Effect of Aminophyllin and Hydrocortisone on the Water Diuresis of a Patient with AdRenal InsUfFICIENCY

In spite of the marked rise in glomerular filtration rate and solute excretion after aminophyllin, the increase in urinary flow and decrease in osmolality were relatively slight. In this patient the pronounced improvement in the water diuresis was associated with an increase in glomerular filtration rate.

even further rise in $\mathrm{C}_{\mathrm{H}_{2} \mathrm{O}}$ to a mean of $4.8 \mathrm{ml}$. per minute while urinary osmolality fell to a mean low of $150 \mathrm{mOsm}$. per $\mathrm{Kg}$. This effect of Compound $\mathrm{F}$ in improving water diuresis could not be explained solely by its effect in increasing glomerular filtration rate or solute excretion. Although the mean glomerular filtration rate after hydrocortisone (103 ml. per minute) was considerably higher than that of the control periods (82 ml. per minute), it was less than the levels attained after aminophyllin (122 ml. per minute). Furthermore, the steroid caused a marked improvement in water diuresis in some cases (Nos. $4,5,9,10$ and 12, Table I) without any significant effect on filtration rate. The excretion of urinary solutes continued to fall following the administration of hydrocortisone to a mean rate of $972 \mu \mathrm{Osm}$. per minute, a marked reduction from the peak of $2,337 \mu \mathrm{Osm}$. per minute attained after aminophyllin or Mercuhydrin ${ }^{\circledR}$. Although a decrease in solute excretion during water diuresis without a change in filtration rate would ordinarily cause a decrease in minimal osmolality (16), it would always cause a decrease in $\mathrm{C}_{\mathrm{H}_{2} \mathrm{O}}$ and urinary flow $(16,31)$ rather than the increase observed after hydrocortisone. The only two patients whose filtration rates decreased following steroids (Nos. 7 and 8, Table I) did not demonstrate an increase in urinary flow. This may have represented some untoward response to the previously administered mercurial. Nevertheless, both displayed a further decrease in urinary osmolality and an increase in $\mathrm{C}_{\mathrm{H}_{2} \mathrm{O}}$.

\section{DISCUSSION}

In the present study, the impaired water excretion of adrenal and pituitary insufficiency could be partially corrected by the administration of aminophyllin or mercurials. Hydrocortisone, however, caused a much greater improvement in all the characteristics of the water diuresis. If these drugs and Compound F-like steroids act primarily at the renal level, it should be possible to fit their actions into the generally accepted schema for the renal tubular reabsorption of solutes and water $(17,19,20,29,31-33)$.

The ability of aminophyllin to improve the water diuresis (a decrease in osmolality and an increase in $\mathrm{C}_{\mathrm{H}_{2} \mathrm{O}}$ ) of those patients excreting a moderately hypertonic urine $(500 \mathrm{mOsm}$. per Kg., Figure 3) is readily explained by its effects on glomerular filtration rate and solute excre-

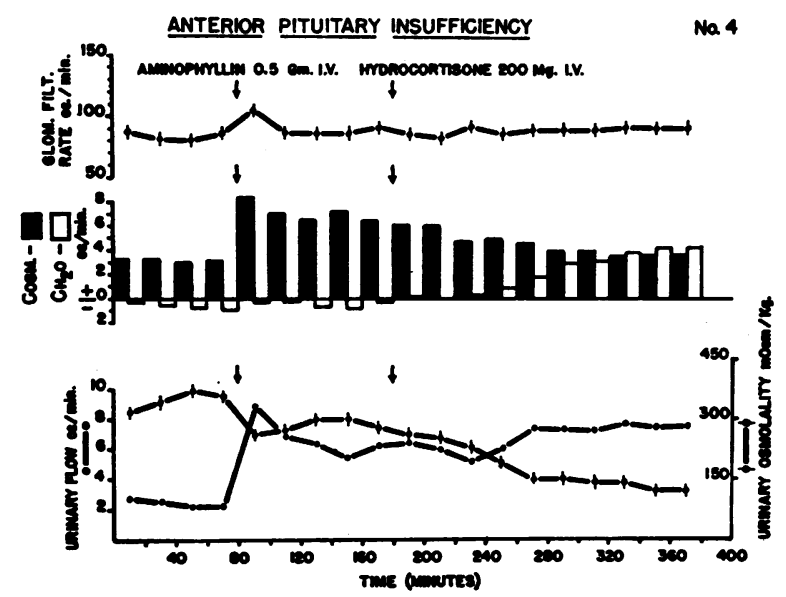

Fig. 6. The Effect of Aminophyllin and Hydrocortisone on the Water Diuresis of a Patient with ANTERIor Pituitary Insufficiency

The rise in filtration rate and solute excretion after aminophyllin caused a large increase in urinary flow with a relatively slight decrease in osmolality. Hydrocortisone caused a further distinct improvement in the water diuresis without a change in filtration rate and a decrease in solute excretion. 
tion. The increase in filtration rate and the inhibition of solute reabsorption in the proximal tubule greatly enhanced the delivery of isosmotic fluid into the distal or diluting segment. Here, in the absence of $\mathrm{ADH}$, a greater volume of hypotonic fluid would be formed. When this volume is decreased by reabsorption of an absolute fixed quantity of water in a terminal concentrating segment (? collecting tubule), the ultimate effect is the production of a greater amount of more dilute urine than that excreted in the control periods. Recent experiments have shown that when the administration of $\mathrm{ADH}$ has caused the production of a slightly hypertonic urine, an acute increase in solute excretion can convert this to a hypotonic urine with an increase in $\mathrm{C}_{\mathrm{H}_{2} \mathrm{O}}(18 ; 21)$. This response would be anticipated from the above schema. The response to Mercuhydrin in the present study can be similarly explained.

The marked improvement in water diuresis caused by hydrocortisone cannot be solely explained by its effects on glomerular filtration and solute excretion. In those patients (Nos. 1, 3, $4,6,10$ and 11 , Table I) in whom the steroid caused an increased filtration rate, this may have contributed to the improved diuresis. If it simultaneously increased the distal reabsorption of solutes, a greater urinary dilution would have occurred, and this was observed. ${ }^{6}$ However, the frequent marked improvement in all parameters of the water diuresis (flow, osmolality, and $\mathrm{C}_{\mathrm{H}_{2} \mathrm{O}}$ ) without a change in filtration rate and with a decrease in solute excretion strongly suggests that hydrocortisone either inhibited the back-diffusion of water in the diluting segment and/or inhibited the back-diffusion or reabsorption of water in the terminal or concentrating segment. It can be argued that Compound $\mathrm{F}$ could have corrected the impaired water diuresis if it blocked proximal tubular reabsorption of a certain fraction of sodium and water and enhanced the reabsorption of sodium in the distal or diluting segment. It seems that had this been an important corrective mechanism, both aminophyllin and Mercuhydrin ${ }^{\circledR}$

\footnotetext{
- In unpublished observations, the authors have noted that 6-methyl-prednisolone (Medroli) can cause an improvement in water diuresis comparable to that following administration of hydrocortisone, and that this analog of Compound $F$ does not increase the net tubular reabsorption of sodium.
}

should have produced more marked improvement in the water diuresis. Both of these drugs greatly increased the delivery of proximal fluid into the distal tubule.

The above explanations assume the absence of endogenous $\mathrm{ADH}$ during the sustained water infusion. The degree and rate of urinary dilution which occurred after the water load was given (Table II) suggests an inhibition of the neurohypophyseal system with a secondary reduction in circulating $\mathrm{ADH}$. In normal subjects, hydrocortisone does not alter the diuretic response curve after a single oral water load $(1,500 \mathrm{ml}$.), does not modify the response of the neurohypophyseal system to osmotic and nonosmotic stimuli and does not antagonize the peripheral action of $\mathrm{ADH}$ (34). Furthermore, earlier investigations have shown 1) that alcohol, a strong inhibitor of the neurohypophyseal system, does not initiate a water diuresis in adrenal insufficiency unless hydrocortisone is previously given $(35,36)$, and 2$)$ that there is no increased sensitivity to or delayed inactivation of $\mathrm{ADH}$ in patients with adrenal and pituitary insufficiency (6). These observations suggest that an extrarenal mechanism altering the metabolism of $\mathrm{ADH}$ is not responsible for the impaired water excretion in these states. An excess of circulating $\mathrm{ADH}$ in adrenal insufficiency has been postulated, based on the detection by bioassay of high levels of antidiuretic substance $(7,8$, 12). The validity and specificity of the bioassay technique utilized have been seriously questioned by Van Dyke, Ames and Plough (13) and Strauss (14).

\section{SUMMARY AND CONCLUSIONS}

1. The diuretic response to a sustained positive water load is markedly impaired in almost all patients with adrenal and pituitary insufficiency.

2. Aminophyllin and Mercuhydrin ${ }^{\otimes}$, by increasing glomerular filtration rate and/or solute excretion, can partially correct this abnormality.

3. The marked improvement in the water diuresis, however, which follows the administration of hydrocortisone, cannot be solely explained by the above mechanisms.

4. The data of the present study strongly suggest that this steroid primarily acts by inhibiting the back-diffusion or reabsorption of water in the loop of Henle, distal tubule, or the concentrating 
segment (? collecting tubule) in the absence of circulating antidiuretic hormone $(\mathrm{ADH})$.

\section{ACKNOWLEDGMENT}

The authors most gratefully acknowledge the technical assistance of Miss Rose Twiss, Miss Whiz Grant, Miss Emma Radler, Mrs. Audrey Bishop and Mr. Joe Yamashita.

\section{APPENDIX}

\section{Summary of cases in Table I}

\section{Anterior pituitary insufficiency}

1. 52 year old male. Chromophobe adenoma of 10 years' duration. Surgically treated. Gonadal, thyroid and adrenal insufficiency. Therapy consisted of testosterone and desiccated thyroid, no adrenal replacement therapy for a month prior to study.

2. 60 year old male. Chromophobe adenoma of 12 years' duration. Treated with irradiation. Gonadal, thyroid and adrenal insufficiency. Therapy consisted of testosterone and desiccated thyroid, no adrenal replacement therapy for two weeks prior to study.

3. 47 year old male. Pituitary infarction of 16 years' duration. Gonadal, thyroid and adrenal insufficiency. Therapy consisted of testosterone and desiccated thyroid, no adrenal replacement therapy for one week prior to study.

4. 58 year old male. Chromophobe adenoma of eight years' duration. Surgically treated. Gonadal, thyroid and adrenal insufficiency. Therapy consisted of testosterone and desiccated thyroid, no adrenal replacement therapy for one month prior to study.

5. 60 year old male. Questionably postencephilitic of 22 years' duration. Gonadal, thyroid and adrenal insuffciency. Therapy consisted of testosterone and desiccated thyroid, no adrenal replacement therapy for two weeks prior to study.

6. 48 year old male. Suprasellar cyst of nine years' duration. Surgically treated. Gonadal, thyroid and adrenal insufficiency. Therapy consisted of testosterone and desiccated thyroid, no adrenal replacement therapy for two months prior to study.

7. 42 year old male. Chromophobe adenoma of six years' duration. Surgically treated and postoperative irradiation. Gonadal, thyroid and adrenal insufficiency. Therapy consisted of tesosterone and desiccated thyroid, no adrenal replacement therapy for one month prior to study.

8. 56 year old male. Chromophobe adenoma of 13 years' duration. Surgically treated and postoperative irradiation. Gonadal, thyroid and adrenal insufficiency. Therapy consisted of testosterone and desiccated thyroid, no adrenal replacement therapy for two weeks prior to study.

\section{Adrenal insufficiency}

9. 27 year old male. Adrenal insufficiency of six years' duration; etiology, idiopathic. No replacement therapy for two weeks prior to study while patient was maintained on high salt diet (10 to $15 \mathrm{Gm}$. per day).

10. 32 year old male. Adrenal insufficiency of 10 years' duration; etiology, tuberculous. No replacement therapy for two weeks prior to study while patient was maintained on high salt diet (10 to $15 \mathrm{Gm}$. per day).

11. 47 year old male. Adrenal insufficiency of nine years' duration; etiology, questionably tuberculous. No replacement therapy for three weeks prior to study while patient was maintained on high salt diet (10 to $15 \mathrm{Gm}$. per day).

12. 58 year old male. Adrenal insufficiency of five years' duration; etiology, idiopathic. No replacement therapy for two weeks prior to study while patient was maintained on high salt diet (10 to $15 \mathrm{Gm}$. per day).

\section{REFERENCES}

1. Rowntree, L. G., and Snell, A. M. A Clinical Study of Addison's Disease. Mayo Clinic Monographs. Philadelphia, W. B. Saunders, 1931.

2. Robinson, J. F., Power, M. H., and Kepler, E. J. Two new procedures to assist in the recognition and exclusion of Addison's disease: A preliminary report. Proc. Mayo Clin. 1941, 16, 577.

3. Garrod, O., and Burston, R. A. The diuretic response to ingested water in Addison's disease and panhypopituitarism and the effect of cortisone thereon. Clin. Sci. 1952, 11, 113.

4. Garrod, O., Davies, S. A., and Cahill, G., Jr. The action of cortisone and desoxycorticosterone acetate on glomerular filtration rate and sodium and water exchange in the adrenalectomized dog. J. clin. Invest. 1955, 34, 761.

5. Levy, M. S., Power, M. H., and Kepler, E. J. Specificity of the "water test" as a diagnostic procedure in Addison's disease. J. clin. Endocr. 1946, $6,607$.

6. Chalmers, T. M., and Lewis, A. A. G. The effect of adrenocorticotropic hormone on the diuretic response to water in panhypopituitarism. Lancet 1951, 2, 1158.

7. Slessor, A. Studies concerning the mechanism of water retention in Addison's disease and in hypopituitarism. J. clin. Endocr. 1951, 11, 700.

8. Gaunt, R., Birnie, J. H., and Eversole, W. J. Adrenal cortex and water metabolism. Physiol. Rev. 1949, 29, 281.

9. Pearson, O. H., Mendelsohn, M. L., and West, C. D. Water and salt metabolism during acute adrenal insufficiency in man. J. clin. Endocr. 1953, 13, 841.

10. Kekwick, A., and Pawan, G. L. S. Oral aldosterone, effect in a case of Addison's disease. Lancet 1954, 2, 162.

11. Prunty, F. T. G., McSwiney, R. R., Mills, I. H., and Smith, M. A. The effects of aldosterone in Ad- 
dison's disease and adrenal pseudohermaphroditism. Lancet 1954, 2, 620.

12. Lloyd, C. W., and Lobotsky, J. Serum antidiuretic substances and urinary corticosteroid in the human. J. clin. Endocr. 1950, 10, 318.

13. Van Dyke, H. B., Ames, R. G., and Plough, I. C. The excretion of antidiuretic hormone in the urine of patients with cirrhosis of the liver. Trans. Ass. Amer. Phycns 1950, 63, 35.

14. Strauss, M. B. Body Water in Man. Boston, Little, Brown and Company, 1957.

15. Rosenbaum, J. D., Nelson, W. P., III, Strauss, M. B., Davis, R. K., and Rossmeisl, E. C. Variations in the diuretic response to ingested water related to the renal excretion of solutes. J. clin. Invest. 1953, 32, 394.

16. Kleeman, C. R., Epstein, F. H., and White, C. The effect of variations of solute excretion and glomerular filtration on water diuresis. J. clin. Invest. 1956, 35, 749.

17. Kleeman, C. R., Maxwell, M. H., and Rockney, R. The production of hypertonic urine in humans in the probable absence of antidiuretic hormone (ADH). Proc. Soc. exp. Biol. (N. Y.) 1957, 96, 189.

18. DeWardener, H. E., and del Greco, F. The influence of solute excretion rate on the production of a hypotonic urine in man. Clin. Sci. 1955, 14, 715.

19. del Greco, F., and DeWardener, H. E. The effect on urine osmolarity of a transient reduction in glomerular filtration rate and solute output during a water diuresis. J. Physiol. 1956, 131, 307.

20. Berliner, R. W., and Davidson, D. G. Production of hypertonic urine in the absence of pituitary antidiuretic hormone. J. clin. Invest. 1957, 36, 1416.

21. Orloff, J., Wagner, H. N., Jr., and Davidson, D. G. The effect of variations in solute excretion and vasopressin dosage on the excretion of water in the dog. J. clin. Invest. 1958, 37, 458.

22. Welt, L. G. The influence of disease on the renal excretion of water in Essays in Metabolism. Boston, Little, Brown and Company, 1957.

23. Raisz, L. G., McNeely, W. F., Saxon, L., and Rosenbaum, J. D. The effects of cortisone and hydrocortisone on water diuresis and renal function in man. J. clin. Invest. 1957, 36, 767.

24. Thorn, G. W., Laidlaw, J. C., and Goldfien, A. Studies on the sodium-retaining effect of adrenal cortical steroids in Ciba Foundation Colloquia on
Endocrinology. Vol. VIII. The Human Adrenal Cortex. Boston, Little, Brown and Company, 1955.

25. Wesson, L. G., Jr., and Anslow, W. P., Jr. Effect of osmotic and mercurial diuresis on simultaneous water diuresis. Amer. J. Physiol. 1952, 170, 255.

26. Rubini, M. E., Kleeman, C. R., and Lamdin, E. Studies on alcohol diuresis. I. The effect of ethyl alcohol ingestion on water electrolyte and acid-base metabolism. J. clin. Invest. 1955, 34, 439.

27. Burston, R. A., and Garrod, O. The variability of the lowered glomerular filtration rate in Addison's disease and panhypopituitarism, and the effect of cortisone thereon. Clin. Sci. 1952, 11, 129.

28. Walser, M., and Orloff, J. The effect of dilution and dehydration in patients with edema and hyponatremia. Clin. Res. Proc. 1957, 5, 114.

29. Zak, G. A., Brun, C., and Smith, H. W. The mechanism of formation of osmotically concentrated urine during the antidiuretic state. J. clin. Invest. 1954, 33, 1064.

30. Rapoport, S., Brodsky, W. A., West, C. D., and Mackler, B. Urinary flow and excretion of solutes during osmotic diuresis in hydropenic man. Amer. J. Physiol. 1949, 156, 433.

31. Surtshin, A., and White, H. L. Postural effects on renal tubular activity. J. clin. Invest. 1956, 35, 267.

32. Smith, H. W. The Kidney: Structure and Function in Health and Disease. New York, Oxford University Press, 1951.

33. Wirz, H. Location of antidiuretic action in the mammalian kidney by micropuncture. Abstracts of Communications, 20th Intern. Physiol. Congress, 1956, p. 972.

34. Kleeman, C. R., Koplowitz, J., Maxwell, M. H., and Rockney, R. Mechanisms of impaired water excretion in adrenal and pituitary insufficiency. II. Interrelationships of hydrocortisone and antidiuretic hormone $(\mathrm{ADH})$. To be published.

35. Lamdin, E., Kleeman, C. R., Rubini, M., and Epstein, F. H. Studies on alcohol diuresis. III. The response to ethyl alcohol in certain disease states characterized by impaired water tolerance. J. clin. Invest. 1956, 35, 386.

36. Gabrilove, J. L. Discussion in An International Symposium on Aldosterone. Boston, Little, Brown and Company, 1958, p. 53. 